\title{
Ethnobotanical Uses and Antimicrobial Properties of Plants in Small-Scale Tropical Fish Farms: The Case of Indonesian Fish Farmers in Java (Indonesia)
}

\author{
Domenico Caruso ${ }^{1}$ \\ IRD -ISEM 226 Université de Montpellier, Bat 22, CC 065, Place Eugène Bataillon 34095, \\ Montpellier cedex 05, France \\ Angela Maria Lusiastuti and Taukhid TAukhid \\ Balai Penelitian dan Pengembangan Budidaya Air Tawar (BPPBAT), Jln. Sempur No 1, Bogor \\ 16154, Indonesia \\ JeAn-Christophe Avarre \\ IRD -ISEM 226 Université de Montpellier, Bat 22, CC 065, Place Eugène Bataillon 34095, \\ Montpellier cedex 05, France \\ Munti Yuhana \\ Fakultas Perikanan dan Ilmu Kelautan, Institut Pertanian Bogor, In. Lingkar Akademic Kampus \\ IPB Darmaga, Bogor 16680, Indonesia \\ SAMIRA SARTER \\ Cirad-ISEM 116, 73 rue Jean-François Breton, Montpellier cedex 05, France
}

\begin{abstract}
Among the most common plants used by fish farmers in Java, 18 were selected for deeper ethnobotanical and laboratory investigation into their antimicrobial activity. These plants are mainly used against fish diseases, but with no precise therapeutic indication, leading to low specificity of use. Leaves, which were the most commonly used part of plants, were generally placed directly in water or less frequently added to the feed. Disk diffusion tests showed that 15 plants of the $18(83 \%)$ displayed varying degrees of antibacterial activity and that Streptococcus agalactiae was more sensitive than Aeromonas hydrophila. Crude ethanolic extracts (EE) were more active than water macerates (WM), and minimum inhibitory concentrations (MICs) ranged from 12.5 to $25 \mathrm{mg} / \mathrm{mL}$. Only the EE of Piper betle had an inhibitory effect against $A$. hydrophila. No MIC was found for any of the WM studied here. Furthermore, both the $\mathrm{EE}$ and, to a lesser extent, the WM of active plants were able to reduce bacterial growth by more than $99 \%$, even at doses below their MICs. These results suggest that these plant extracts have a potential for eco-friendly prevention of bacterial fish diseases.
\end{abstract}

Fish diseases are considered to be a serious threat to the sustainability of aquaculture, and global outbreaks contribute to the loss of several billion US dollars per year (Subasinghe 2005). It has been shown that diseases and health problems particularly affect small-scale aquaculture, as reported in several Asian countries (Mazid

\footnotetext{
${ }^{1}$ Correspondence to: domenico.caruso@ird.fr
}

and Banu 2002; Somga et al. 2002; Faruk et al. 2004; Leung and Bates 2013).

Indeed, poor health management and misdiagnosis of diseases by fish farmers can lead to misuse of antibiotics in aquaculture, with an impact on both human health and the environment, which also threatens the sustainability of the fish-farming industry. Sanitary hazards related to residues of antibiotics in fish flesh and the spread of antibiotic resistance to pathogenic 
or commensal bacteria in aquaculture are well documented (Cabello 2006; Sarter et al. 2007). As a result, the use of antibiotics in aquaculture is now the subject of strict regulations in many countries. Hence, there is an urgent need for sustainable alternatives, in particular, for the development of herbal therapy, which is recognized to be a promising, effective, and eco-friendly alternative to the use of antibiotics or drugs in fish and shrimp farming (Reverter et al. 2014; Valladão et al. 2015).

Considering the extent of plant diversity, the selection of plant candidates is a complex task. Compounds derived from ethnobotanical studies have greater pharmaceutical properties than those selected by random screening and therefore have greater potential for the development of innovative therapeutic products (Flaster 1996). Several ethnobotanical parameters, including the fidelity level or the informant consensus factor, are frequently used to select plants (Ali-Shtayeh et al. 2000). However, they require specific knowledge about disease diagnosis and the corresponding plant use, which the fish farmers generally do not have. The use value (UV) (Upadhyay et al. 2011), a quantitative method that evaluates the relative importance of plant species known locally, may be a valuable alternative. An ethnobotanical survey performed in Western Java revealed that 26 of the 79 plants used by fish farmers had a high UV (above 0.025) (Caruso et al. 2013). These 26 plants can be considered the most frequently used ones in herbal therapy by fish farmers in West Java. Two additional ethnobotanical surveys were carried out in 2013-2014 to collect supplementary and more detailed information about their use. The surveys covered 70 fish farmers in different villages in Bogor district (West Java) and 380 in Central Java province. Among the 26 frequently used plants, 18 were randomly selected for the determination of their antimicrobial activity. The antimicrobial activity of plant extracts depends on the solvents used for extraction or maceration (Eloff 1998). Hence, an organic solvent (95\% ethanol) and an inorganic solvent (bidistilled water) were used in this study.
The objectives of this study were (1) to understand how small-scale fish farmers in Java use plants and (2) to perform an in vitro evaluation of their antimicrobial properties against two pathogenic fish bacteria, a Gram-positive Streptococcus agalactiae and a Gram-negative Aeromonas hydrophila, both of which have a high incidence in tropical aquaculture (Pridgeon and Klesius 2013).

\section{Materials and Methods}

\section{Ethnobotanical Surveys}

A knowledge, attitude, and practices (KAP) study (Vigneron et al. 2005) was included in both the surveys. The KAP questionnaire was based on closed (yes/no) and open (what, which, and who) questions (total $n=81$ ), including sections related to diseases and health management and to the use of plants. The questionnaire was tested on a subsample of fish farmers, and an inquirer was specially trained to conduct the survey. The resulting ethnobotanical indications (Table 1) correspond to the ratio of specific use of a plant to the total number of respondents who use the plant, expressed as a percentage.

\section{Plants and Preparation of Plant Extracts}

Leaves of the plants (Table 1) were purchased from the Indonesian Medicinal and Aromatic Crops Research Institute in Cimanggu, Bogor, and bulbs and rhizomes were purchased at a local market. The leaves, bulbs, and rhizomes were cleaned, wiped, cut, and oven dried at 55-60 C for $15-20 \mathrm{~h}$; dried plants were then ground in an electric mill, sieved with a tea strainer, and stored at $25 \mathrm{C}$ in an airtight container until use. Ethanolic extraction and water maceration were carried out in triplicate for each plant. Ten grams of each plant powder were soaked in either $95 \%$ ethanol or bidistilled water at a ratio of $1: 10(\mathrm{w} / \mathrm{v})$, and then gently shaken on a shaking table at room temperature $(25 \mathrm{C})$ for $72 \mathrm{~h}$ (in triplicate). Macerates were filtered three times, with two sieves of different sizes $(1.2 \pm 0.6 \mathrm{~mm})$ and finally filtered with Whatman filter paper $(125 \mathrm{~mm})$. For water maceration, the samples were centrifuged at $10,000 \mathrm{~g}$ for $10 \mathrm{~min}$ after 
the third filtration and the supernatants were filtered $(0.22 \mu \mathrm{m}$ sieve $)$ to avoid bacterial contamination. Ethanolic extracts (EE) were evaporated in a rotary evaporator (Ogawa Seiki Ltd., Tokyo, Japan, 40 C; 100-120 rpm, for 4-10 h depending on the plant). For the disk diffusion test, we used ethanol to dissolve the dry extracts and to ensure complete evaporation of the solvent on the disk. For these extracts, the yield was determined as the percentage of dry extract per dry plant. Water macerates (WM) and EE were stored at $4 \mathrm{C}$ until antimicrobial assays, which started about 1 mo later.

\section{Antibacterial Susceptibility Assays}

The S. agalactiae and A. hydrophila used in this study had previously been isolated and identified from diseased Oreochromis niloticus and Clarias gariepinus, respectively, and stored in $20 \%$ glycerol at $-20 \mathrm{C}$. They were grown for $24 \mathrm{~h}$ on brain heart $(\mathrm{BH})$ infusion agar (Oxoid) and Muller-Hinton (MH) agar (Difco) plates, respectively, then suspended in sterile phosphate buffered saline (PBS) to reach a concentration of $1.5 \times 10^{8} \mathrm{CFU} / \mathrm{mL}$.

The disk diffusion test was carried out according to the CLSI (2005) (at a temperature of $34 \pm 2 \mathrm{C}$ instead of $28 \mathrm{C}$ ) for all EE and WM. Sterile Whatman paper disks (diameter $6 \mathrm{~mm}$ ) were soaked with $20 \mu \mathrm{L}$ of plant extracts and placed on plates. Plant WM were used directly, whereas EE were first dissolved in $95 \%$ ethanol $(100 \mathrm{mg} / \mathrm{mL})$ and the corresponding disks were placed on plates after ethanol evaporation for $3 \mathrm{~min}$ at room temperature. A disk containing $30 \mu \mathrm{g}$ of chloramphenicol was used as a positive control and another disk soaked with 95\% ethanol (or water as appropriate) was used as a negative control. After 24-h incubation at $34 \pm 2 \mathrm{C}$, the diameter of the inhibition zone was measured with a caliper. Tests were carried out in triplicate. The efficacy comparative index (ECI, in \%) was calculated as the ratio of the average inhibition diameters of plant extracts to those induced by the reference antibiotic (chloramphenicol, 30 $\mu \mathrm{g}$, Oxoid). The plant extracts whose inhibition zone was greater than $6 \mathrm{~mm}$ in diameter in the disk diffusion test were used to determine their minimum inhibitory concentration (MIC) using the macrodilution method. Stock solutions of WM were mixed at a 1:1 ratio with double-strength $\mathrm{MH}$ broth for A. hydrophila and with BHI broth for $S$. agalactiae. EE $(200 \mathrm{mg})$ were dissolved in $2 \mathrm{~mL}$ of sterile distilled water containing $100 \mathrm{mg}$ of Tween 80 , then mixed with $2 \mathrm{~mL}$ of double-strength $\mathrm{MH}$ broth or BHI broth. Both stock solutions had a final concentration of $50 \mathrm{mg} / \mathrm{mL}$. Serial dilutions were carried out in 11 tubes (concentrations ranging from 25 to $0.0475 \mathrm{mg} / \mathrm{mL}$ ) and an additional one with no extract was used as a negative control. Bacterial inoculum of $1 \mathrm{~mL}$ obtained from cultures of A. hydrophila and S. agalactiae (grown for $24 \mathrm{~h}$ at $34 \mathrm{C}$ ) at $7.8 \times 10^{5}$ and $6.9 \times 10^{5} \mathrm{CFU} / \mathrm{mL}$, respectively, was added to each of the 12 tubes.

As visual determination of MIC was not possible owing to the color of the extracts, $50 \mu \mathrm{L}$ of each dilution was mixed with $1 \mathrm{~mL}$ of sterile PBS and then serially diluted down to $10^{-6}$. For each dilution, $50 \mu \mathrm{L}$ was spread on $\mathrm{BH}$-infusion agar or Tripticase Soya Agar (Oxoid) plates and bacterial colonies were counted after $24 \mathrm{~h}$ of incubation at $34 \mathrm{C}$. The MIC (expressed as $\mathrm{mg} / \mathrm{mL}$ ) was defined as the lowest concentration of the plant extract at which the microbial concentration did not increase compared with the initial inoculum.

The inhibition rate (IR) of bacterial growth caused by plant extracts was calculated as follows and expressed as a percentage:

$$
\begin{gathered}
\text { IR }(\%)=\left(\mathrm{TPC}_{\text {cont } 24 \mathrm{~h}}-\mathrm{TPC}_{\text {plant } 24 \mathrm{~h}} /\right. \\
\left.\mathrm{TPC}_{\text {cont } 24 \mathrm{~h}}\right) \times 100,
\end{gathered}
$$

where TPC is the total plate count of bacteria after 24-h incubation at $34 \pm 2 \mathrm{C}$.

\section{Statistics}

Normality and equal variance were checked with Kolmogorov-Smirnov and Levene median tests, respectively. One-way ANOVA was used for comparisons of means, followed by Holm-Sidak test for pairwise differences. When normality and equal variance were not detected, a nonparametric Kruskal-Wallis one-way ANOVA on rank was used. Yield data were Ln 
transformed and percentages and frequencies were compared with $\chi^{2}$ or $z$ tests. For all tests, $\alpha$ was set at 0.05 .

\section{Results}

Table 1 summarizes all the ethnobotanical information collected on the uses of the 18 plants used by the fish farmers in Java. Leaves were the most commonly used part of the plants $(60 \%)$, but in the case of the plants belonging to the Zingiberaceae or Liliaceae families, only the rhizomes were used. Balneation was the most prevalent way to apply the plants. Generally leaves were used whole but in some instances they were chopped or crushed before used. $(z=7.896, P<0.001$, $n=203$ ). The selected plants were mainly used against fish diseases rather than to improve water quality, 70 versus $30 \% \pm 4.7 \%$ (I.C interval of confidence for both percentages), ( $z$ test $=6.946, P<0.001, n=367)$. Fish farmers used the plants indifferently to prevent or treat diseases and there was no significant difference between the two uses $(z=0.191$, $P 0.849, n=251$ ). Information provided by the fish farmers concerning therapeutic indications was vague and more than $50 \%$ of fish farmers chose the response "no symptoms"; the highest ranked symptom, "cutaneous symptoms," was cited by $25 \%$ of the fish farmers. It also appeared that fish farmers may use the same plants for many purposes, including improving water quality and increasing fish resistance to diseases.

After ethanol evaporation, the yields of EE ranged from 1.43 to $16.2 \%$ (Fig. 1), but yields from the leaves of the trees were significantly higher $(P<0.001)$ than from the leaves of herbaceous plants, or rhizomes and bulbs.

Figure 2 shows the results of disk diffusion against $S$. agalactiae and A. hydrophila obtained from the EE and WM of plants. With the exception of Colocasia esculenta, Gliricidia sepium, and Parkia speciosa, most plants (15 out of 18 plants, $83 \%$ ) exhibited antibacterial activity. The number of EE effective against $S$. agalactiae was significantly higher $(n=15 ; 83 \%)$ than WM $\left(n=5 ; 28 \%, \chi^{2}=9.113, \mathrm{df}=1, P=0.003\right)$ (Fig. 2A, B). The EE of only four plants (22\%) displayed minimal antibacterial activity against A. hydrophila, and no inhibition was detected with WM (Fig. 2C). When a plant showed antimicrobial activity after both types of maceration, the inhibition diameters of EE were significantly larger than those of WM $(P<0.001)$. The median value of the ECI was significantly higher with $\mathrm{EE}(P=0.016)$.

Significantly more plants were effective against $S$. agalactiae than against $A$. hydrophila $\left(\chi^{2}=11,146, \mathrm{df}=1, P<0.001\right)$, and their diameter of inhibition was larger $(P<0.001$ for all comparisons). For the $\mathrm{EE}$ of the four plants showing effective activity against both bacteria, the median value of inhibition was higher against $S$. agalactiae than against $A$. hydrophila ( $P<0.001$ for all comparisons) (Fig. 2A, B).

The MIC against $S$. agalactiae was $12.5 \mathrm{mg} / \mathrm{mL}$ for Curcuma domestica, Curcuma zanthorrhiza, Curcuma zedoaria, Phyllanthus niruri, Piper betle, and Plectranthus scutellarioides; and $25 \mathrm{mg} / \mathrm{mL}$ for Ageratum conyzoides, Austroeupatorium inulaefolium, Terminalia catappa, and Tithonia diversifolia. On the other hand, among the EE of the four plants effective against $A$. hydrophila, $P$. betle was the only one with an MIC of $25 \mathrm{mg} / \mathrm{mL}$. The MICs of the other plants were higher than $25 \mathrm{mg} / \mathrm{mL}$. The IRs of the EE and WM of plants against both bacteria after $24 \mathrm{~h}$ of growth at $34 \pm 2 \mathrm{C}$ are listed in Table 2. IRs of over $90 \%$ were observed for all effective plants. Three plants, Plectranthus scutellaroides, A. inulaefolium, and $P$. niruri, had an IR $>90 \%$ at the lowest concentration tested $(0.781 \mathrm{mg} / \mathrm{mL})$.

\section{Discussion}

The limited knowledge of fish farmers about fish diseases proved to be an obstacle to a clear understanding of the relationships between plants and diseases. The use of plants with no clearly identified therapeutic indications suggests that the fish farmers use the plants pragmatically and with low specificity. However, our ethnobotanical surveys revealed that use of natural compounds plays an important role in health management in small-scale fish farming in Java. Fish farmers recognize that 


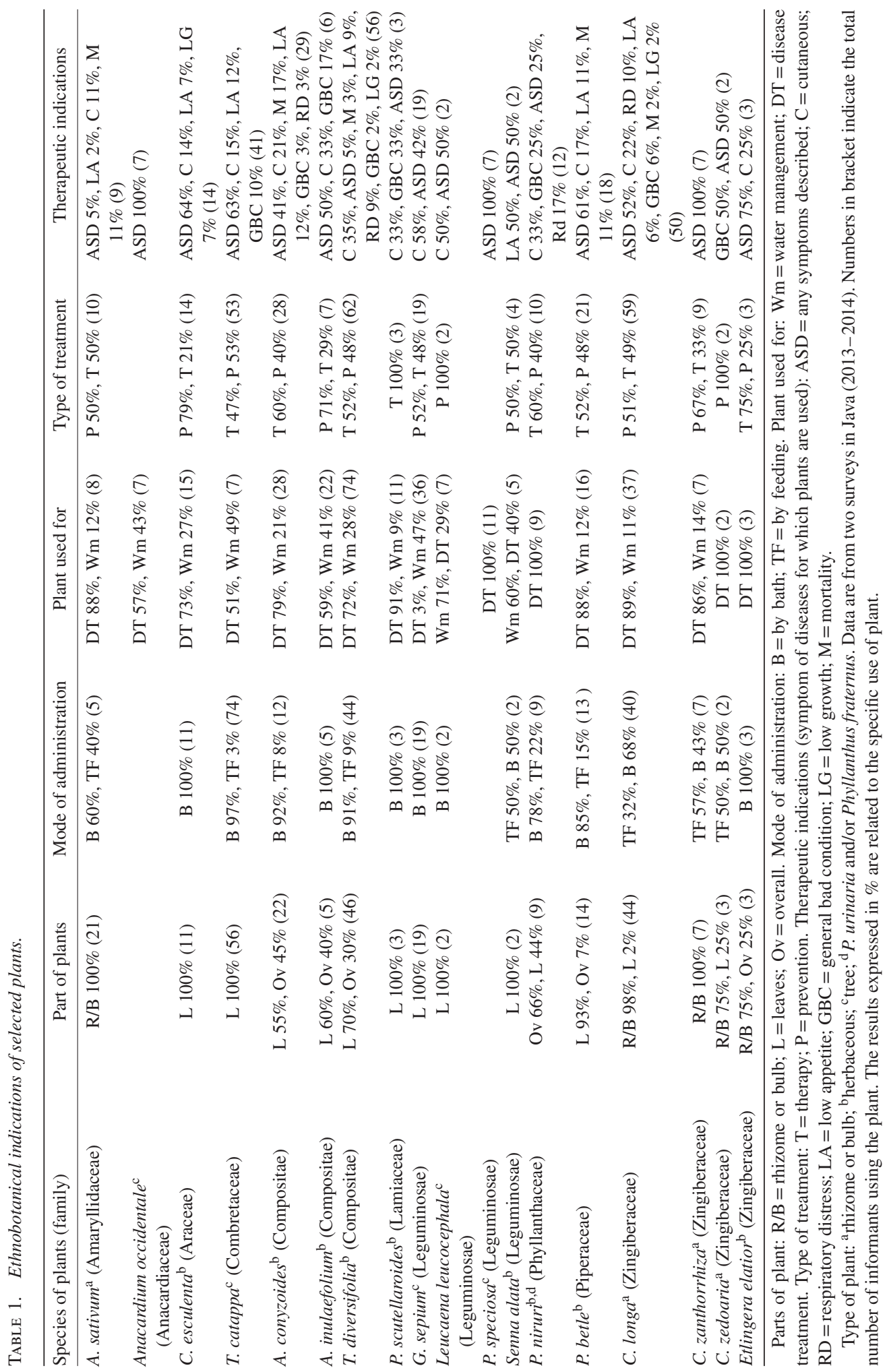




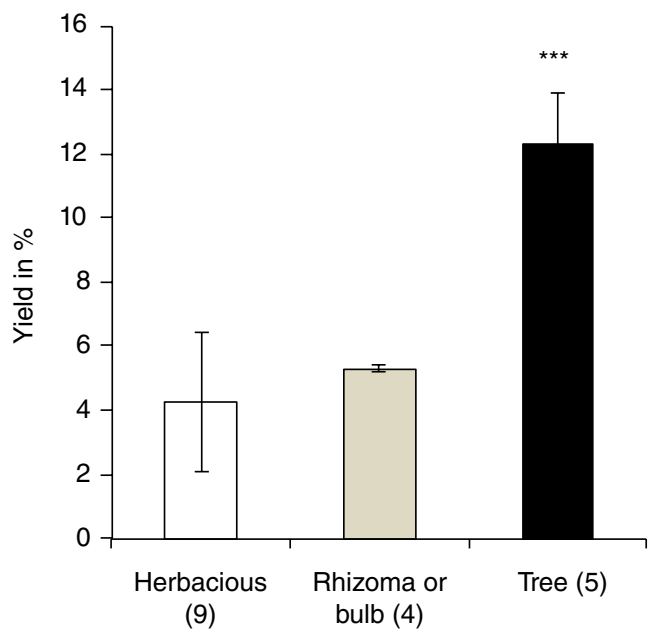

FIGURE 1. Yields of dry extract obtained after ethanolic extraction and evaporation according to the type of plants. The number in bracket indicates the number of species of plants that have been processed. Herbaceous plants were A. conyzoides, A. inulaefolium, C. esculenta, E. elatior, P. scutellaroides, P. niruri, P. betle, S. alata, and $\mathrm{T}$. diversifolia. Rhizome plants were A. sativum, C. longa, C. zanthorrhiza, and C. zedoaria. Tree plants were A. occidentale, G. sepium, L. leucocephala, P. speciosa, and T. catappa. Data are expressed as average $\pm S D,{ }^{* * *} \mathrm{P}<0.001$ (one-way ANOVA and Holm-Sidak method).

plants have different actions, but in the case of the plants studied here, they mainly use them for the prevention or treatment of fish diseases. Moreover, 15 of the 18 plants (i.e. 83\%) with a high UV were shown to have antibacterial activity in this analysis. This high validation rate suggests that this generic ethnobotanical indicator may be a reliable way to select plant candidates for sustainable pharmacopeia in aquaculture. Considering the widespread use of these plants against disease, ethnobotanical surveys can help to advance research on herbal therapy for aquaculture. In this study, yields of ethanolic dry extracts depended more on the species of plants (herbaceous versus ligneous plants) than on the part of the plant (leaf or rhizome) used for extraction. These differences may be linked to the higher amount of polysaccharides (both cellulose and lignin) in the leaves of trees than in leaves of herbaceous plants (Schädel et al. 2010).
Our results confirm that EE have higher antimicrobial activity than WM, as already reported in the literature (Parekh et al. 2005; Parekh and Chanda 2008; Das et al. 2010). The entire extraction process is of major importance for the antimicrobial activity of plants, and obviously, a high rate of extraction or yield of dry extract will play a decisive role in the selection of a plant. Yield and other important pharmaceutical properties - including antimicrobial activity - are closely linked with the process of extraction (Eloff 1998; Cowan 1999; Nostro et al. 2000), and new techniques may improve the efficacy and safety of herbal compounds.

However, because all, even the simplest, methods are costly and time consuming, they cannot be afforded by Javanese fish farmers. We therefore suggest the use of WM of active plants only for small volumes of water such as aquaria or small tanks, where an effective concentration can be reached. In larger facilities, which would require larger quantities of plants, it may be more appropriate to use dry plants in fish feed.

The antimicrobial activities of EE and WM revealed by disk diffusion tests are in agreement with the results obtained with the liquid method used here to determine MIC. The disk diffusion test allows rapid detection of antimicrobial activity and is suitable for screening a wide range of plants and extracts. However, it is only a qualitative indication of bioactive plants (Nostro et al. 2000; Langfield et al. 2004), which should be followed up with more accurate quantitative methods.

Our results support other findings showing that Gram-positive bacteria are generally more sensitive to plant extracts than Gram-negative ones (Burt 2004; Hussain et al. 2010). Yet several natural compounds can be effective against Gram-negative bacteria (Genovese et al. 2012; Fankam et al. 2014). Natural compounds may cause structural damage, particularly to the bacterial membrane (Cowan 1999). In contrast to Gram-positive bacteria, Gram-negative bacteria possess an outer bilayered membrane with porins (Pagès 2004). These structural differences may explain the variability in antibacterial activity against the bacteria evaluated here. 
(A)

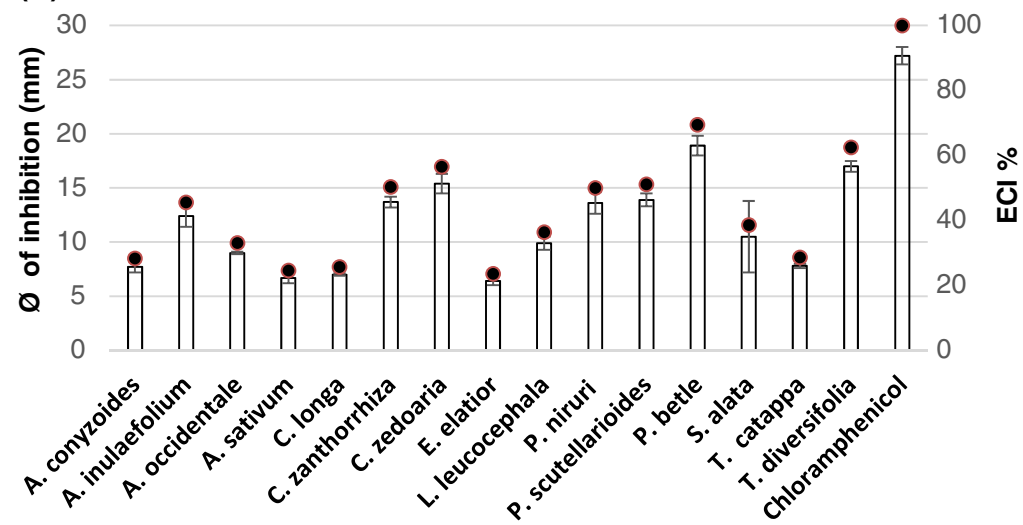

(B)

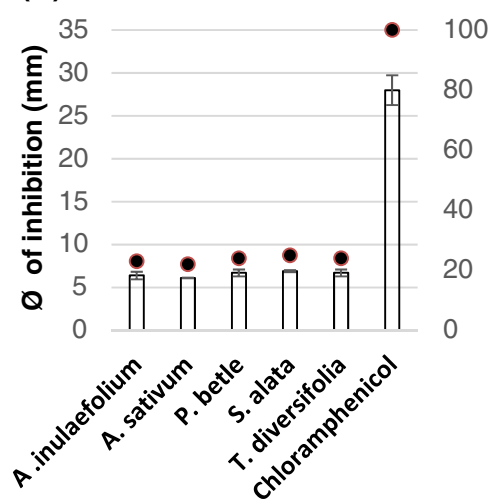

(C)

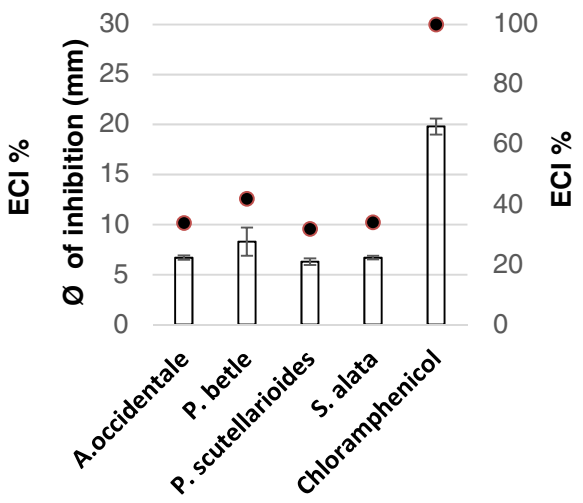

FIGURE 2. Disk diffusion test of ethanolic extracts of plants against $\mathrm{S}$. agalactiae. (A) Disk diffusion test of water macerates of plants against $\mathrm{S}$. agalactiae. (B) Disk diffusion test of ethanolic extracts of plants against A. hydrophila. (C) Bars show the diameters of bacterial inhibition as mean $\pm S D(\mathrm{n}=9)$. The black dots show the efficiency comparative index $(E C I)$.

According to Pankey and Sabath (2004), a compound has a bacteriostatic effect when it reduces bacterial growth by 90 to $99 \%$ and a bactericidal effect when it kills $>99.9 \%$ of bacteria in the initial bacterial inoculum. According to this definition, only four plants $(C$. zanthorrhiza, $P$. betle, $P$. niruri, and $P$. scutellarioides) among those tested here can be considered as bacteriostatic against $S$. agalactiae. Two plants of the Zingiberaceae family (Curcuma longa and C. zedoaria) have already been evaluated in fish health management (Sahu et al. 2008; Chowdhury and Rahman 2012). In contrast, there has been no study of $C$. zanthorrhiza. This rhizome is capable of stimulating the immune function of macrophage cells in rats (Kim et al. 2007) and is a promising candidate for aquaculture.
Piper betle is also a promising candidate for aquaculture; in this study, it displayed activity against both bacteria; its EE was the only one able to reduce bacterial growth of A. hydrophila, even at a low concentration $(6.25 \mathrm{mg} / \mathrm{mL})$. The effect of $P$. betle against fish pathogens has already been highlighted (Muniruzzaman and Chowdhury 2004; Albert and Ransangan 2013), but as far as we know, the antibacterial properties of P. niruri, Austroeupatorium inulifolium, and $P$. scutellaroides against fish pathogens in aquaculture have never been reported. EEs of $P$. niruri have already been successfully tested against human enteropathogenic bacteria (Ekwenye and Njoku 2006), and activity against fish bacteria has been reported for Phyllanthus urinaria, a species belonging to the same genus and very 
TABLE 2. Inhibition rate (IR \%) of ethanolic extracts (EE) and water macerates (WM) of plants both against $\mathrm{S}$. agalactiae and $A$. hydrophila growth after 24 hat $34 \mathrm{C}$.

\begin{tabular}{|c|c|c|c|c|c|c|}
\hline \multirow[b]{2}{*}{ Plant EE } & \multicolumn{6}{|c|}{ Inhibition rate $(\%)$ against $S$. agalactiae ${ }^{a}$} \\
\hline & $25 \mathrm{mg} / \mathrm{mL}$ & $12.5 \mathrm{mg} / \mathrm{mL}$ & $6.25 \mathrm{mg} / \mathrm{mL}$ & $3.125 \mathrm{mg} / \mathrm{mL}$ & $1.562 \mathrm{mg} / \mathrm{mL}$ & $0.781 \mathrm{mg} / \mathrm{mL}$ \\
\hline A. conyzoides & ++ & ++ & + & - & - & - \\
\hline A. sativum & ++ & ++ & - & - & - & - \\
\hline A. occidentale & ++ & ++ & ++ & + & - & - \\
\hline A. inulaefolium & ++ & ++ & ++ & ++ & + & + \\
\hline C. domestica & ++ & ++ & ++ & - & - & - \\
\hline C. zanthorrhiza & +++ & ++ & ++ & ++ & + & - \\
\hline C. zedoaria & +++ & +++ & ++ & ++ & + & - \\
\hline E. elatior & ++ & ++ & + & - & - & - \\
\hline L. leucocephala & ++ & ++ & + & + & - & - \\
\hline P. niruri & +++ & ++ & ++ & ++ & + & + \\
\hline P. betle & +++ & ++ & ++ & ++ & + & - \\
\hline P. scutellarioides & +++ & +++ & ++ & ++ & ++ & ++ \\
\hline S. alata & ++ & + & + & + & - & - \\
\hline T. catappa & +++ & ++ & ++ & + & - & - \\
\hline T. diversifolia & ++ & ++ & ++ & ++ & + & - \\
\hline \multirow[t]{2}{*}{ Plant WM } & \multicolumn{6}{|c|}{$\begin{array}{l}\text { IR (\%) against } S . \text { agalactiae }^{\mathrm{b}} \\
\text { Dilution of plant macerates }\end{array}$} \\
\hline & $1: 2$ & $1: 4$ & $1: 8$ & $1: 16$ & $1: 32$ & $1: 64$ \\
\hline A. sativum & ++ & - & - & - & - & - \\
\hline A. inulaefolium & ++ & + & - & - & - & - \\
\hline P. betle & ++ & - & - & - & - & - \\
\hline T. diversifolia & ++ & - & - & - & - & - \\
\hline S. alata & ++ & - & - & - & - & - \\
\hline \multirow{2}{*}{ Plant EE } & \multicolumn{6}{|c|}{ Inhibition rate (\%) against $A$. hydrophila ${ }^{\mathrm{c}}$} \\
\hline & $25 \mathrm{mg} / \mathrm{mL}$ & $12.5 \mathrm{mg} / \mathrm{mL}$ & $6.25 \mathrm{mg} / \mathrm{mL}$ & $3.125 \mathrm{mg} / \mathrm{mL}$ & $1.562 \mathrm{mg} / \mathrm{mL}$ & $0.781 \mathrm{mg} / \mathrm{mL}$ \\
\hline A. sativum & + & - & - & - & - & - \\
\hline A. occidentale & + & - & - & - & - & - \\
\hline P. betle & ++ & ++ & ++ & - & - & - \\
\hline Cassia alata & + & - & - & - & - & - \\
\hline P. scutellarioides & - & - & - & - & - & - \\
\hline
\end{tabular}

IR $<90 \%=-;$ IR $\geq 90=+;$ IR $\geq 99 \%=++;$ IR $\geq 99.99 \%=+++$.

${ }^{\mathrm{a} C o n t r o l}$ concentration $=9.12 \pm 0.16 \log _{10} \mathrm{CFU} / \mathrm{mL}$ (average $\pm \mathrm{SD}, n=15$ ).

${ }^{\mathrm{b}}$ Control concentration $=9.20 \pm 0.12 \log _{10} \mathrm{CFU} / \mathrm{mL}$ (average $\pm \mathrm{SD}, n=5$ ).

${ }^{\mathrm{c}}$ Control concentration $=9.16 \pm 0.20 \log _{10} \mathrm{CFU} / \mathrm{mL}$ (average $\pm \mathrm{SD}, n=6$ ).

similar to $P$. niruri (Muniruzzaman and Chowdhury 2004). Likewise, EEs of A. inulifolium have been found to act against Staphylococcus aureus (Álvarez et al. 2005). No reports of the antimicrobial activity of $P$. scutellarioides have appeared in the literature, but this plant is used to heal skin infections, wounds, and sores in Papua New Guinea (Nick et al. 1995).

Consistent reductions ( $\geq 90 \%)$ in bacterial concentration may contribute to the effectiveness of plants in controlling populations of opportunistic or pathogenic bacteria in fish farming. Indeed,
T. catappa or Allium sativum, which showed low antibacterial activity in this study, have been found to be effective against fish diseases, even at concentrations lower than those we tested in vitro (Chitmanat et al. 2005; Nya and Austin 2009). Plant antibacterial activity may also be related to anti-quorum sensing properties (Koh et al. 2013) and the immuno-stimulation induced by plants may improve fish resistance against bacteria (Vaseeharan and Thaya 2014; Van Hai 2015). Hence, a multidisciplinary approach should be considered for a better understanding 
of the biological activities of plants in fish. Antibacterial plants may greatly contribute to the reduction of the excessive use of antibiotics. They should be recommended as an alternative because they are inexpensive, renewable, and locally available, and their use is generally recognized to be safe. According to the IR recorded in this study, the use of plants with high antimicrobial activities should be recommended to fish farmers as both a WM and in the feed. These plants may reduce the bacterial load in the fish gut or in the water, thereby reducing the pressure exerted by opportunistic fish pathogens.

At the same time, the current pragmatic use of plants should be scientifically assessed and refined to increase the efficacy and ensure the sustainability of herbal therapy in fish farming.

\section{Acknowledgments}

We are grateful to the French Ministry of Foreign Office (MAE), in the frame of the Bio-Asia program, for partly funding the project ESTAFS (Ethnobotany for Sustainable Therapy in Aquaculture and Food Safety), and to the Institut Francais d'Indonésie (IFI) of the French Embassy (Jakarta, Indonesia). We also thank Ms. Widyastuti. This is publication IRD-DIVA-ISEM N ${ }^{\circ}$ 2016-145 SUD.

\section{Literature Cited}

Albert, V. and J. Ransangan. 2013. Antibacterial potential of plant crude extracts against Gram negative fish bacterial pathogens. International Journal of Research in Pharmaceutical and Biosciences 3:21-27.

Ali-Shtayeh, M. S., Z. Yaniv, and J. Mahajna. 2000. Ethnobotanical survey in the Palestinian area, a classification of the healing potential of medicinal plants. Journal of Ethnopharmacology 73:221-232.

Álvarez, M. E., G. Isaza, and H. M. Echeverry. 2005. Efecto antibacteriano in vitro de Austroeupatorium inulaefolium H.B.K. (Salvia amarga) y Ludwigia polygonoides H.B.K. (Clavo de laguna). Biosalud 14:46-55.

Burt, S. 2004. Essential oils: their antibacterial properties and potential applications in foods - a review. International Journal of Food Microbiology 94:223-253.

Cabello, F. C. 2006. Heavy use of prophylactic antibiotics in aquaculture, a growing problem for human and animal health and for the environment. Environmental Microbiology 8:1137-1144.

Caruso, D., A. M. Lusiastuti, T. Taukhid, J. Slembrouck, O. Komarudin, and M. Legendre. 2013. Traditional pharmacopeia in small scale freshwater fish farms in West Java, Indonesia, an ethnoveterinary approach. Aquaculture 416:334-345.

Chitmanat, C., K. Tongdonmuan, P. Khanom, P. Pachontis, and W. Nunsong. 2005. Antiparasitic, antibacterial, and antifungal activities derived from a Terminalia catappa solution against some tilapia (Oreochromis niloticus) pathogen. Acta Horticulturae 678:179-182.

Chowdhury, M. B. R. and T. Rahman. 2012. Use of low-cost chemotherapeutic and medicinal plants against Thai silver barb (Barbonymus gonionotus). Journal of the Bangladesh Agricultural University 10:385-390.

CLSI (Clinical and Laboratory Standards Institute). 2005. Methods for antimicrobial disk susceptibility testing of bacteria isolated from aquatic animals; proposed guideline, Clinical and Laboratory Standards Institute 25:1-43.

Cowan, M. M. 1999. Plant products as antimicrobial agents. Clinical Microbiology Reviews 12:564-582.

Das, K., R. K. S. Tiwari, and D. K. Shrivastava. 2010. Techniques for evaluation of medicinal plant products as antimicrobial agent: current methods and future trends. Journal of Medicinal Plants Research 4:104-111.

Ekwenye, U. N. and N. U. Njoku. 2006. Antibacterial effect of Phyllanthus niruri (Chanca Piedra) on three enteropathogens in man. International Journal of Molecular Medicine and Advance Sciences 2:184-189.

Eloff, J. N. 1998. Which extractant should be used for the screening and isolation of antimicrobial components from plants? Journal of Ethnopharmacology 60:1-8.

Fankam, A. G., J. R. Kuiate, and V. Kuete. 2014. Antibacterial activities of Beilschmiedia obscura and six other Cameroonian medicinal plants against multi-drug resistant Gram-negative phenotypes. BMC Complementary and Alternative Medicine 14:1.

Faruk, M. A. R., M. M. R. Sarker, M. J. Alam, and M. B. Kabir. 2004. Economic loss from fish diseases on rural freshwater aquaculture of Bangladesh. Pakistan Journal of Biological Sciences 7:2086-2091.

Flaster, T. 1996. Ethnobotanical approaches to the discovery of bioactive compounds. Pages 561-565 in J. Janick, editor. Progress in new crops. ASHS Press, Arlington, Virginia, USA.

Genovese, G., C. Faggio, C. Gugliandolo, A. Torre, A. Spanò, M. Morabito, and T. L. Maugeri. 2012. In vitro evaluation of antibacterial activity of Asparagopsis taxiformis from Straits of Messina against pathogens relevant in aquaculture. Marine Environmental Research 73:1-6.

Hussain, A. I., F. Anwar, P. S. Nigam, M. Ashraf, and A. H. Gilani. 2010. Seasonal variation in content, chemical composition and antimicrobial and cytotoxic activities of essential oils from four Mentha species. Journal of the Science of Food and Agriculture 90:1827-1836.

Kim, A. J., Y. O. Kim, J. S. Shim, and J. K. Hwang. 2007. Immunostimulating activity of crude polysaccharide 
extract isolated from Curcuma xanthorizza Rox. Bioscience 71:1428-1438.

Koh, C. L., C. K. Sam, W. F. Yin, L. Y. Tan, T. Krishnan, Y. M. Chong, and K. G. Chan. 2013. Plant-derived natural products as sources of anti-quorum sensing compounds. Sensors 13:6217-6228.

Langfield, R. D., F. J. Scarano, M. E. Heitzman, M. Kondo, G. B. Hammond, and C. C. Neto. 2004. Use of a modified microplate bioassay method to investigate antibacterial activity in the Peruvian medicinal plant Peperomia galioides. Journal of Ethnopharmacology 94:279-281.

Leung, T. L. and A. E. Bates. 2013. More rapid and severe disease outbreaks for aquaculture at the tropics, implications for food security. Journal of Applied Ecology 50:215-222.

Mazid, M. A. and A. N. H. Banu. 2002. An overview of the social and economic impact and management of fish and shrimp disease in Bangladesh, with an emphasis on small-scale aquaculture. FAO Fisheries Technical Paper:21-25.

Muniruzzaman, M. and M. B. R. Chowdhury. 2004. Sensitivity of fish pathogenic bacteria to various medicinal herbs. Bangladesh Journal of Veterinary Medicine 2:75-82.

Nick, A., T. Rali, and O. Stiche. 1995. Biological screening of traditional medicinal plants from Papua New Guinea. Journal of Ethnopharmacology 49:147-156.

Nostro, A., M. P. Germano, V. D'angelo, A. Marino, and M. A. Cannatelli. 2000. Extraction methods and bioautography for evaluation of medicinal plant antimicrobial activity. Letters in Applied Microbiology 30:379-384.

Nya, E. J. and B. Austin. 2009. Allium sativum, to control Aeromonas hydrophila infection in rainbow trout, Oncorhynchus mykiss (Walbaum). Journal of Fish Diseases 32:963-970.

Pagès, J. M. 2004. Porines bactériennes et sensibilité aux antibiotiques. Medicine Sciences 20:346-351.

Pankey, G. A. and L. D. Sabath. 2004. Clinical relevance of bacteriostatic versus bactericidal mechanisms of action in the treatment of Gram-positive bacterial infections. Clinical Infectious Diseases 38:864-870.

Parekh, J. and S. Chanda. 2008. Antibacterial activities of aqueous and alcoholic extracts of 34 Indian medicinal plants against some Staphylococcus species. Turkish Journal of Biology 32:63-71.

Parekh, J., D. Jadeja, and S. Chanda. 2005. Efficacy of aqueous and methanol extracts of some medicinal plants for potential antibacterial activity. Turkish Journal of Biology 29:203-210.
Pridgeon, J. and P. H. Klesius. 2013. Major bacterial diseases in aquaculture and their vaccine development. Animal Science Reviews 2012:141-156.

Reverter, M., N. Bontemps, D. Lecchini, B. Banaigs, and P. Sasal. 2014. Use of plant extracts in fish aquaculture as an alternative to chemotherapy, current status and future perspectives. Aquaculture 433:50-61.

Sahu, S., B. K. Das, B. K. Mishra, J. Pradhan, S. K. Samal, and N. Sarangi. 2008. Effect of dietary Curcuma longa on enzymatic and immunological profiles of rohu, Labeo rohita (Ham.), infected with Aeromonas hydrophila. Journal of Applied Ichthyology 39:1720-1730.

Sarter, S., H. N. K. Nguyen, L. T. Hung, J. Lazard, and D. Montet. 2007. Antibiotic resistance in Gram-negative bacteria isolated from farmed catfish. Food Control 18:1391-1396.

Schädel, C., A. Blöchl, A. Richter, and G. Hoch. 2010. Quantification and monosaccharide composition of hemicelluloses from different plant functional types. Plant Physiology and Biochemistry 48:1-8.

Somga, J. R., S. S. Somga, and M. B. Reantaso. 2002. Impacts of disease on small-scale grouper culture in the Philippines. FAO Fisheries Technical Paper: 207-214.

Subasinghe, R. P. 2005. Epidemiological approach to aquatic animal health management, opportunities and challenges for developing countries to increase aquatic production through aquaculture. Preventive Veterinary Medicine 67:117-124.

Upadhyay, B., K. P. Singh, and A. Kumar. 2011. Ethno-veterinary uses and informants consensus factor of medicinal plants of Sariska region, Rajasthan, India. Journal of Ethnopharmacology 133:14-25.

Valladão, G. M. R., S. U. Gallani, and F. Pilarski. 2015. Phytotherapy as an alternative for treating fish disease. Journal of Veterinary Pharmacology and Therapeutics 38:417-428.

Van Hai, N. 2015. The use of medicinal plants as immunostimulants in aquaculture, a review. Aquaculture 446:88-96.

Vaseeharan, B. and R. Thaya. 2014. Medicinal plant derivatives as immunostimulants, an alternative to chemotherapeutics and antibiotics in aquaculture. Aquaculture International 22:1079-1091.

Vigneron, M., X. Deparis, E. Deharo, and G. Bourdy. 2005. Antimalarial remedies in French Guiana, a knowledge attitudes and practices study. Journal of Ethnopharmacology 98:351-360. 